\title{
Protein phosphatase 2A affects myofilament contractility in non-failing but not in failing human myocardium
}

\author{
Paul J. M. Wijnker · Peter Boknik • Ulrich Gergs • Frank U. Müller • \\ Joachim Neumann • Cris dos Remedios • Wilhelm Schmitz • Jürgen R. Sindermann • \\ Ger J. M. Stienen • Jolanda van der Velden • Uwe Kirchhefer
}

Received: 21 July 2011/Accepted: 9 September 2011/Published online: 30 September 2011

(C) The Author(s) 2011. This article is published with open access at Springerlink.com

\begin{abstract}
Protein phosphatase (PP) type 2A is a multifunctional serine/threonine phosphatase that is involved in cardiac excitation-contraction coupling. The PP2A core enzyme is a dimer, consisting of a catalytic $\mathrm{C}$ and a scaffolding A subunit, which is targeted to several cardiac proteins by a regulatory B subunit. At present, it is controversial whether PP2A and its subunits play a critical role in end-stage human heart failure. Here we report that the application of purified $\mathrm{PP} 2 \mathrm{~A}_{\mathrm{C}}$ significantly increased the $\mathrm{Ca}^{2+}$-sensitivity $\left(\triangle \mathrm{pCa}_{50}=0.05 \pm 0.01\right)$ of the contractile apparatus in isolated skinned myocytes of non-failing (NF) hearts. A higher phosphorylation of troponin I (cTnI) was found at protein kinase A sites (Ser23/24) in NF compared to failing myocardium. The basal $\mathrm{Ca}^{2+}$-responsiveness of myofilaments was enhanced in myocytes of ischemic (ICM, $\Delta \mathrm{pCa}_{50}=0.10 \pm 0.03$ ) and dilated (DCM,
\end{abstract}

P. J. M. Wijnker $(\bowtie) \cdot$ G. J. M. Stienen · J. van der Velden Laboratory for Physiology, Institute for Cardiovascular Research, VU University Medical Center, Van der

Boechorststraat 7, 1081 BT Amsterdam, The Netherlands e-mail: p.wijnker@vumc.nl

P. Boknik · F. U. Müller · W. Schmitz · U. Kirchhefer Institut für Pharmakologie und Toxikologie,

Universitätsklinikum Münster, Münster, Germany

U. Gergs · J. Neumann

Institut für Pharmakologie und Toxikologie,

Martin-Luther-Universität Halle-Wittenberg, Halle, Germany

C. dos Remedios

Muscle Research Unit, Institute for Biomedical Research,

The University of Sydney, Sydney, Australia

J. R. Sindermann

Klinik und Poliklinik für Thorax-, Herz- und Gefäßchirurgie,

Universitätsklinikum Münster, Münster, Germany
$\left.\Delta \mathrm{pCa}_{50}=0.06 \pm 0.04\right)$ cardiomyopathy compared to NF. However, in contrast to NF myocytes the treatment with $\mathrm{PP} \mathrm{A}_{\mathrm{C}}$ did not shift force-pCa relationships in failing myocytes. The higher basal $\mathrm{Ca}^{2+}$-sensitivity in failing myocytes coincided with a reduced protein expression of PP2 $A_{C}$ in left ventricular tissue from patients suffering from ICM and DCM (by 50 and 56\% compared to NF, respectively). However, PP2A activity was unchanged in failing hearts despite an increase of both total PP and PP1 activity. The expression of PP2 $\mathrm{A}_{\mathrm{B} 56 \alpha}$ was also decreased by 51 and $62 \%$ in ICM and DCM compared to NF, respectively. The phosphorylation of cTnI at Ser23/24 was reduced by 66 and $49 \%$ in ICM and DCM compared to NF hearts, respectively. Our results demonstrate that PP2A increases myofilament $\mathrm{Ca}^{2+}$-sensitivity in $\mathrm{NF}$ human hearts, most likely via cTnI dephosphorylation. This effect is not present in failing hearts, probably due to the lower baseline cTnI phosphorylation in failing compared to nonfailing hearts.

Keywords Protein phosphatase 2A - Myofilament function - Protein phosphorylation - Cardiomyocyte . Troponin I

\section{Introduction}

The balance between protein kinases and opposing phosphatases is crucial for normal cell function in all tissues. Disruption of this balance between protein phosphorylation and dephosphorylation can trigger dysfunction and disease. Protein phosphatases are emerging as significant regulators in cellular signaling pathways. Protein phosphatase 2A (PP2A) has been identified as one important modulator of cellular processes, including regulation of ion channels and 
transporters, apoptosis, transcription, development, intercellular communication, and excitation-contraction coupling (Herzig and Neumann 2000; Janssens and Goris 2001).

This serine/threonine phosphatase consists of a heterotrimer that includes a dimeric core enzyme, containing a catalytic $\mathrm{C}$ subunit and a structural/scaffolding A subunit (Shi 2009). The core enzyme is bound to a variety of exchangeable regulatory B subunits, governing substrate specificity, subcellular targeting, and enzymatic activity (McCright et al. 1996; Price and Mumby 2000). One of the four unrelated gene families of the B subunit is B' (or B56). Its members are encoded by five distinct genes, generating a variety of splicing isoforms, and are preferentially expressed in cardiac muscle (Ito et al. 2003; Zhou et al. 2007). Although there is growing knowledge about the structural properties of PP2A subunits, there is little information on their distribution and functional interplay in normal and diseased myocardium.

In the heart, PP2A is associated with the $\beta$-adrenergic receptor, connexin43, $\mathrm{Na}^{+} / \mathrm{Ca}^{2+}$ exchanger, L-type $\mathrm{Ca}^{2+}$ channel, ryanodine receptor (RyR), phospholamban (PLB), troponin I (cTnI), and myosin light chain 2 (MLC-2), representing critical molecules in cellular excitability and myocardial contractility (Ai and Pogwizd 2005; Chen et al. 2003; Deshmukh et al. 2007; Hall et al. 2006; Macdougall et al. 1991; Marx et al. 2000; Schulze et al. 2003). In intact myocytes localization of the $\mathrm{PP} 2 \mathrm{~A}$ regulatory $\mathrm{B}$ subunit at the sarcomeres is altered by activation of e.g. the $\beta$-adrenergic receptor (Deshmukh et al. 2007; Yin et al. 2010). The importance of PP2A targeting was tested in transgenic mice expressing a dominant negative mutant of the A subunit, which cannot bind regulatory B subunits, resulting in an altered sub-cellular localization of the enzyme, dilated cardiomyopathy, and depressed contractility (Brewis et al. 2000). The crucial role of PP2A in regulating cardiac $\mathrm{Ca}^{2+}$ signaling has been further demonstrated by application of the purified enzyme to isolated rat myocytes which was accompanied by a reduction of cytosolic $\mathrm{Ca}^{2+}$ transients (duBell et al. 1996). This is in line with data from a transgenic mouse model with heartdirected overexpression of $\mathrm{PP} 2 \mathrm{~A}_{\mathrm{C} \alpha}$ showing a lower phosphorylation state of PLB and cTnI, hypertrophy, and impaired contractile function (Gergs et al. 2004). In the latter study (Gergs et al. 2004) increased diastolic $\mathrm{Ca}^{2+}$ levels were observed in cardiomyocytes from the PP2Aoverexpressing transgenic mice, which may be due to the reduced phosphorylation of PLB and coincident reduced reuptake of $\mathrm{Ca}^{2+}$ into the sarcoplasmic reticulum (SR) via the $\mathrm{SR} \mathrm{Ca}^{2+}$-ATPase. In contrast, application of PP2A inhibitors like cantharidin and calyculin A was associated with an increased phosphorylation of PLB, higher L-type $\mathrm{Ca}^{2+}$ currents and $\mathrm{Ca}^{2+}$ transients, and enhanced force of contraction (Boknik et al. 2001; duBell et al. 2002). These effects were independent of an increase in intracellular cAMP, an altered myofilament $\mathrm{Ca}^{2+}$-sensitivity, or $\mathrm{K}^{+}$ current inhibition (duBell et al. 2002; Neumann et al. 1994, 1995). Because a number of studies suggested a regulatory role of PP2A in normal myocardium and in animal models of the diseased heart, we hypothesized that the activity state of the PP2A multimeric complex is important for the progression of human heart failure.

Thus, the aim of the present study was to determine the functional relevance of PP2A by measuring the $\mathrm{Ca}^{2+}$. sensitivity of myofilaments in the presence and absence of $\mathrm{PP} 2 \mathrm{~A}_{\mathrm{C}}$ in isolated skinned myocytes of non-failing and failing human hearts. Moreover, we tested whether potential effects in myofilament $\mathrm{Ca}^{2+}$-sensitivity are paralleled by changes in PP2A expression and activity in failing hearts. Finally, we examined if differences in myofilament responsiveness to PP2A and in PP expression/activity correspond with the phosphorylation status of myofilament proteins in failing and non-failing human myocardium.

\section{Methods}

Human myocardial tissue

Right (RV) and left ventricular (LV) tissue was obtained from patients undergoing heart transplantation due to endstage heart failure resulting from ischemic (ICM) or dilated cardiomyopathy (DCM) and from non-failing hearts (NF) that could not be transplanted due to medical reasons or blood group incompatibility (Table 1). Most patients received diuretics, cardiac glycosides, ACE inhibitors, and carvedilol (for detailed information see Table 1). Myocardial tissue was quickly transferred to cold cardioplegic solution and upon arrival in the laboratory, stored in liquid nitrogen. Care was taken not to use scarred, fibrotic, adipose samples, endocardium, epicardium, or great vessels. Tissue was frozen within $1 \mathrm{~h}$ of explantation. Permissions for the study were obtained from the local Ethic's Committees of the University Hospital of Münster and the St Vincents' Hospital Human Research Ethics Committee in Sydney, Australia (File number: H03/118; Title: Molecular Analysis of Human Heart Failure). The investigation conformed with the principles outlined in the Declaration of Helsinki.

Isolation and skinning of myocytes

Myocytes from LV of non-failing and failing hearts were mechanically isolated on ice as described previously (van 
Table 1 Patient characteristics

\begin{tabular}{|c|c|c|c|c|c|c|c|}
\hline Age & Gender & Diagnosis & NYHA & $\mathrm{EF}$ & CI & PCWP & Drugs \\
\hline 63 & $\mathrm{M}$ & NF & & & & & n.d. \\
\hline 44 & M & $\mathrm{NF}$ & & & & & n.d. \\
\hline 69 & M & $\mathrm{NF}$ & & & & & n.d. \\
\hline 23 & M & $\mathrm{NF}$ & & & & & n.d. \\
\hline 19 & M & $\mathrm{NF}$ & & & & & n.d. \\
\hline n.d. & n.d. & $\mathrm{NF}$ & & & & & n.d. \\
\hline 48 & M & ICM & III-IV & & 2.5 & 18 & $\mathrm{D}, \mathrm{G}, \mathrm{N}, \mathrm{A}, \mathrm{C}$ \\
\hline 58 & M & ICM & IV & & 2.2 & 22 & $\mathrm{D}, \mathrm{G}, \mathrm{N}, \mathrm{A}$ \\
\hline 41 & $\mathrm{~F}$ & ICM & & & & & \\
\hline 51 & M & ICM & & & & & \\
\hline 60 & M & ICM & III-IV & 25 & 2.7 & 30 & $\mathrm{D}, \mathrm{G}, \mathrm{A}, \mathrm{R}$ \\
\hline 61 & M & ICM & & & 2.8 & 11 & A, B \\
\hline 52 & M & ICM & & 20 & 1.7 & 18 & $\mathrm{D}, \mathrm{G}, \mathrm{C}$ \\
\hline 43 & M & ICM & III-IV & & 2.0 & 11 & $\mathrm{D}, \mathrm{N}, \mathrm{A}, \mathrm{C}$ \\
\hline 32 & $\mathrm{~F}$ & ICM & & & & & \\
\hline 47 & M & ICM & & & 3.1 & 16 & \\
\hline n.d. & n.d. & ICM & n.d. & n.d. & n.d. & n.d. & n.d. \\
\hline 61 & M & DCM & II-III & & 1.8 & 21 & $\mathrm{D}, \mathrm{G}, \mathrm{N}, \mathrm{C}, \mathrm{R}$ \\
\hline 53 & M & DCM & III & 25 & 2.4 & 22 & $\mathrm{D}, \mathrm{D}, \mathrm{A}, \mathrm{C}, \mathrm{R}$ \\
\hline 57 & M & DCM & III-IV & $10-20$ & 2.6 & 17 & $\mathrm{D}, \mathrm{G}, \mathrm{N}, \mathrm{A}, \mathrm{C}$ \\
\hline 49 & M & DCM & & & & & \\
\hline 51 & M & DCM & III-IV & 14 & 2.9 & 29 & $\mathrm{D}, \mathrm{G}, \mathrm{N}, \mathrm{A}$ \\
\hline 52 & M & DCM & II-III & & 2.8 & 11 & $\mathrm{D}, \mathrm{G}, \mathrm{A}, \mathrm{C}, \mathrm{R}$ \\
\hline 43 & M & DCM & IV & 19 & & & $\mathrm{G}, \mathrm{A}, \mathrm{C}$ \\
\hline 36 & M & DCM & III & & 2.5 & 26 & $\mathrm{D}, \mathrm{A}, \mathrm{C}$ \\
\hline 50 & M & DCM & IV & & & & $\mathrm{D}, \mathrm{C}$ \\
\hline 27 & $\mathrm{M}$ & DCM & & & 3.4 & 4 & \\
\hline
\end{tabular}

$E F(\%) \mathrm{LV}$ ejection fraction, $C I\left(1 / \mathrm{min}^{2}\right)$ cardiac index, $P C W P(\mathrm{mmHg})$ pulmocapillary wedge pressure, $D$ diuretics, $G$ glycosides, $N$ nitrates, $A$ ACE inhibitors or angiotensin II receptor antagonists, $C$ carvedilol, $R$ antiarrhythmics, $B \beta$-adrenergic receptor blockers

der Velden et al. 1998). In the ICM group myocytes were isolated from the non-ischemic remodeled part of the left ventricle. Briefly, tissue was thawed in isolation solution containing $10 \mathrm{mmol} / \mathrm{l}$ imidazole ( $\mathrm{pH} 7.0$ ), $140 \mathrm{mmol} / \mathrm{l}$ $\mathrm{KCl}, 6 \mathrm{mmol} / \mathrm{l} \mathrm{Na}{ }_{2} \mathrm{ATP}, 2 \mathrm{mmol} / \mathrm{l} \mathrm{EGTA}$, and $6 \mathrm{mmol} / \mathrm{l}$ $\mathrm{MgCl}_{2}$. All membrane structures of isolated myocytes were dissolved by incubation with the isolation solution supplemented with $0.5 \%$ Triton $\mathrm{X}-100$ for $5 \mathrm{~min}$ at $4^{\circ} \mathrm{C}$. At this temperature the kinases and the phosphatases are inactive and therefore during myocyte isolation and skinning the phosphorylation status remains unchanged. In addition, after skinning all the soluble and membranebound protein kinases and phosphatases are washed away by washing three times with Triton-free isolation solution. The phosphorylation status of myofibrillar proteins is not affected by the procedure (Duncker et al. 2009; Kooij et al. 2010a, b; van der Velden et al. 2003a). Skinned myocytes were kept at $4^{\circ} \mathrm{C}$ up to $24 \mathrm{~h}$.
Measurement of force- $\left[\mathrm{Ca}^{2+}\right]$ relation in skinned myocytes

The use of skinned myocytes allows the study of myofibrillar contractility under standardized conditions, i.e. composition of intracellular buffer and sarcomere length. Measurement of isometric force was performed at $15^{\circ} \mathrm{C}$ and sarcomere length was set to $2.2 \mu \mathrm{m}$ (van der Velden et al. 2003b). The composition of relaxing and activating solutions ( $\mathrm{pH}$ 7.1) was calculated as described (Fabiato 1981). The $\mathrm{pCa}$ value, i.e. $-\log _{10}\left[\mathrm{Ca}^{2+}\right]$, of the relaxing and activating solution were set to 9.0 and 4.5 , respectively. Solutions with intermediate free $\left[\mathrm{Ca}^{2+}\right]$ were obtained by appropriate mixing. Measurement of isometric force was started with a first activation of the myocyte at a $\mathrm{pCa}$ value of 4.5 . The second activation was used to determine maximal isometric tension. The next measurements were performed at submaximal $\left[\mathrm{Ca}^{2+}\right]$, followed by 
a final control measurement at maximal $\left[\mathrm{Ca}^{2+}\right]$ $(\mathrm{pCa}=4.5)$. Force values at submaximal $\left[\mathrm{Ca}^{2+}\right]$ were normalized to interpolated control values, taking into account a linear reduction in maximal force with each activation. This force- $\left[\mathrm{Ca}^{2+}\right]$ relationship was repeated after treatment with exogenous PP2A. For this purpose, myocytes were incubated for $40 \mathrm{~min}$ at $20^{\circ} \mathrm{C}$ in relaxing solution containing $5 \mathrm{U} / \mathrm{ml}$ of the active or heat-inactivated catalytic subunit $(\alpha / \beta)$ of PP2A (Promega). At this temperature PP2A is active and dephosphorylates its target proteins. PP2A was not present in the solutions used during the tension-pCa measurements. Incubation for $40 \mathrm{~min}$ at $20^{\circ} \mathrm{C}$ in relaxing solution without PP2A did not change phosphorylation status of the myofilament proteins (unpublished data). Force- $\left[\mathrm{Ca}^{2+}\right]$ relations were fit to a modified Hill equation (van der Velden et al. 2003a). The maximal rate of force redevelopment ( $\max k_{t r}$ ) was determined from an exponential curve fit of force redevelopment after a slack test in activating solution with pCa 4.5.

Immunological detection of PP2A subunits

Frozen RV and LV tissue of human hearts was homogenized at $4{ }^{\circ} \mathrm{C}$ for $90 \mathrm{~s}$ in a buffer containing $20 \mathrm{mmol} / 1 \mathrm{Tris} /$ $\mathrm{HCl}$ (pH 7.4), 1 mmol/l EDTA, 5 mmol/l $\mathrm{MgCl}_{2}, 1 \mathrm{mmol} / 1$ DTT, and protease inhibitors. After incubation for $20 \mathrm{~min}$ on ice samples were centrifuged at $15,800 \times g$ for $15 \mathrm{~min}$. Supernatants were diluted in 5\% SDS buffer containing $62.5 \mathrm{mmol} / \mathrm{l} \mathrm{Tris} / \mathrm{HCl}$ (pH 6.8), 5\% glycerol, and $40 \mathrm{mmol} /$ 1 DTT. For immunoblot analysis different amounts of solubilized proteins were separated electrophoretically in $10 \%$ SDS-polyacrylamide gels. Proteins were transferred to nitrocellulose for immunoblotting. Nitrocellulose sheets were probed with different antibodies: polyclonal anti-PP2 $\mathrm{A}_{\mathrm{C} \alpha / \beta}$ antibody (Santa Cruz Biotechnology), a polyclonal anti-A $\alpha$ antibody (Santa Cruz), a polyclonal anti-B56 $\alpha$ antibody (Santa Cruz), and a polyclonal anticalsequestrin antibody (Kirchhefer et al. 2001). Antibody binding was visualized by alkaline phosphatase-conjugated secondary antibodies (Amersham Biosciences) or by ${ }^{125}$ I-labeled protein A (PerkinElmer) followed by autoradiography. Labeling intensities were quantified with use of a PhosphorImager.

Analysis of the phosphorylation status of myofilament proteins

LV samples were TCA(trichloroacetic acid)-treated as described previously (Zaremba et al. 2007). Samples were separated on a gradient gel (Criterion Tris- $\mathrm{HCl} 4-15 \%$ gel, BioRad) and proteins were stained for $1 \mathrm{~h}$ with ProQ Diamond Phosphoprotein Stain (Molecular Probes)
(Hamdani et al. 2010). Staining was visualized using the LAS-3000 Image Reader (FUJI; 460 nm/605 nm Ex/Em; 2 min illumination) and signals were analyzed with AIDA. Subsequently, gels were stained overnight with SYPRO Ruby stain (Molecular Probes) and visualized with the LAS-3000. ProQ-stained phosphorylated proteins were normalized to SYPRO Ruby-stained myosin binding protein C (cMyBP-C) to correct for differences in sample loading. Gel electrophoresis and Western blotting was performed to analyze bisphosphorylation of cTnI at PKA sites Ser23/24 (rabbit polyclonal antibody, Cell Signaling; dilution 1:500). Signals were normalized to actin to correct for differences in protein loading.

Incubation of myofilaments with PP2A

To assess the effect of PP2A on myofilament protein phosphorylation, NF myocardium was isolated and skinned as described above (as for force measurements) and incubated in relaxing solution with $0.5 \mathrm{U}$ or $5 \mathrm{U}$ exogenous $\mathrm{PP} 2 \mathrm{~A}_{\mathrm{C}}$ for $40 \mathrm{~min}$ at $\mathrm{RT}$. In the control incubation no PP2A was added to NF tissue. After incubation, protein was isolated via the 2-D Clean-Up Kit (GE Healthcare) and dissolved in 1D-sample buffer containing $15 \%$ glycerol (v/v), $62.5 \mathrm{mM}$ Tris (pH 6.8), 1\% (w/v) SDS and 2\% (w/v) DTT. To determine the phosphorylation status of the myofilament proteins ProQ Diamond Phosphoprotein Stain was used. The amount of phosphorylation of cTnI-Ser23/ 24 was studied via Western blotting.

\section{Protein phosphatase assay}

PP activity was determined with $\left[{ }^{32} \mathrm{P}\right]$-phosphorylase $a$ as substrate (Boknik et al. 2000). Portions of pulverized frozen LV tissue were homogenized at $4^{\circ} \mathrm{C}$ for $3 \times 30 \mathrm{~s}$ each with a Polytron in a buffer containing $4 \mathrm{mmol} / \mathrm{l}$ EDTA and $15 \mathrm{mmol} / \mathrm{l} \beta$-mercaptoethanol ( $\mathrm{pH} 7.4$ ). The homogenate was centrifuged for $20 \mathrm{~min}$ at $14,000 \times \mathrm{g}$. The incubation mixture contained $20 \mathrm{mmol} / \mathrm{l}$ Tris/ $\mathrm{HCl}$ (pH 7.0), $5 \mathrm{mmol} / \mathrm{l}$ caffeine, $0.1 \mathrm{mmol} / \mathrm{l}$ EDTA, and $0.1 \% \beta$-mercaptoethanol ( $\mathrm{vol} / \mathrm{vol})$. The reaction was started by adding aliquots of supernatants, and $3 \mathrm{nmol} / \mathrm{l}$ okadaic acid was used to differentiate between $\mathrm{PP} 1$ and $\mathrm{PP} 2 \mathrm{~A}$ activity. The reaction was stopped by addition of 50\% TCA. Precipitated protein was sedimented by centrifugation, and the radioactivity was counted in the supernatant.

\section{Statistics}

Data are reported as means \pm SEM. Statistical differences between groups were calculated by ANOVA followed by Bonferroni's $t$-test. $P<0.05$ was considered significant. 


\section{Results}

PP2A increases force development at submaximal $\left[\mathrm{Ca}^{2+}\right]$ in NF myofilaments

To investigate whether the dephosphorylation of contractile proteins by PP2A directly influences isometric force development, we applied the catalytic subunit of the enzyme to skinned myocytes from NF hearts. For this purpose, single myocytes were attached between a force transducer and a piezoelectric motor (Fig. 1a). All experiments were performed on the stage of an inverted microscope. In Fig. 1b representative recordings of force development before and after application of $\mathrm{PP} 2 \mathrm{~A}_{\mathrm{C}}$ at saturating $(\mathrm{pCa}=4.5)\left[\mathrm{Ca}^{2+}\right]$ are shown. Treatment of myocytes with $\mathrm{PP} \mathrm{A}_{\mathrm{C}}$ did not change maximal or passive isometric force (Table 2). Representative recordings of force development at submaximal ( $\mathrm{pCa}$ values ranged from 5.0 to 6.0 ; here $\mathrm{pCa}=5.4)\left[\mathrm{Ca}^{2+}\right]$ are shown in Fig. $1 \mathrm{~b}$ and demonstrate a higher force development after PP2A treatment indicating that $\mathrm{Ca}^{2+}$-sensitivity is modulated by the enzyme in NF myocytes. Indeed, the measurement of the force-pCa relationship (Fig. 1c) revealed a higher $\mathrm{Ca}^{2+}$-responsiveness of the myofilaments after incubation with PP2 $\mathrm{A}_{\mathrm{C}}$ as evidenced by an enhanced $\mathrm{pCa}_{50}$ value $\left(\Delta \mathrm{pCa}_{50}=0.05 \pm 0.01\right)$. Incubation of skinned myocytes with heat-inactivated PP2A did not shift force$\mathrm{pCa}$ relationship demonstrating an enzyme-specific effect (data not shown).
Fig. 1 The image shows a single NF myocyte in relaxing solution attached between a force transducer and a piezoelectric motor (a). Shown are original recordings (b) of isometric force development in a Triton-skinned NF myocyte before and after treatment with $\mathrm{PP} 2 \mathrm{~A}_{\mathrm{C}}$. The force was recorded at a sarcomere length of $2.2 \mu \mathrm{m}$ during maximal activation at $\mathrm{pCa}=4.5$ and submaximal activation at $\mathrm{pCa}=5.4$. Force increases when the myocyte is transferred from the relaxing solution $(\mathrm{pCa}=9.0)$ into the activating solution. After reaching steady state force, the cardiomyocyte was $20 \%$ reduced in length within $2 \mathrm{~ms}$ and re-stretched after $30 \mathrm{~ms}$ (slack test). During this slack test, force first dropped to zero and after the re-stretch quickly redeveloped to the original steady state level. Subsequently, the cell was transferred back to relaxing solution and a second slack test was started to determine passive force. The active force of a myocyte is the steady state force (maximal force) minus the passive force. The summarized force-pCa relationship is given $(\mathbf{c} ; 6 \mathrm{NF}$, 14 cells) (a)
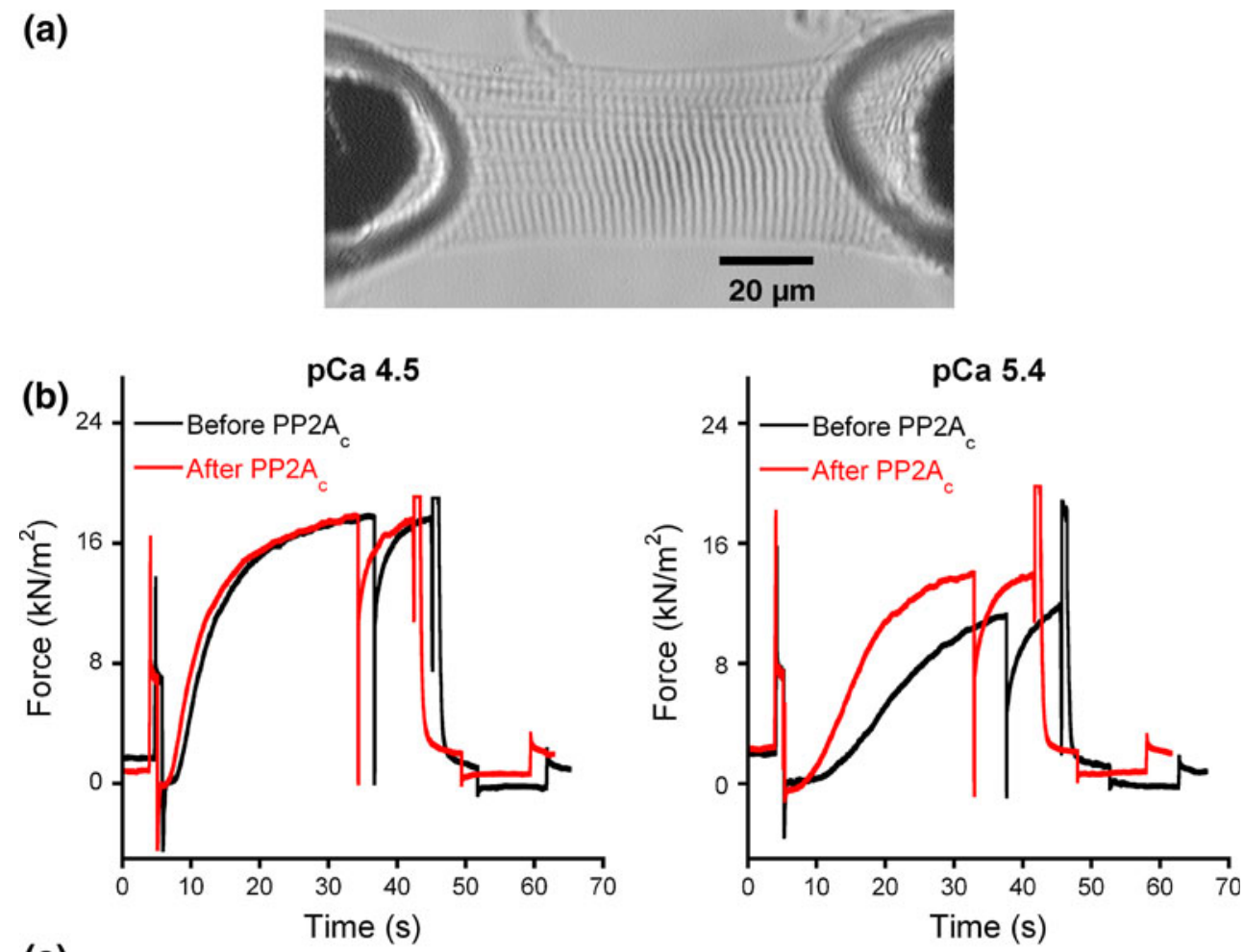

(c)

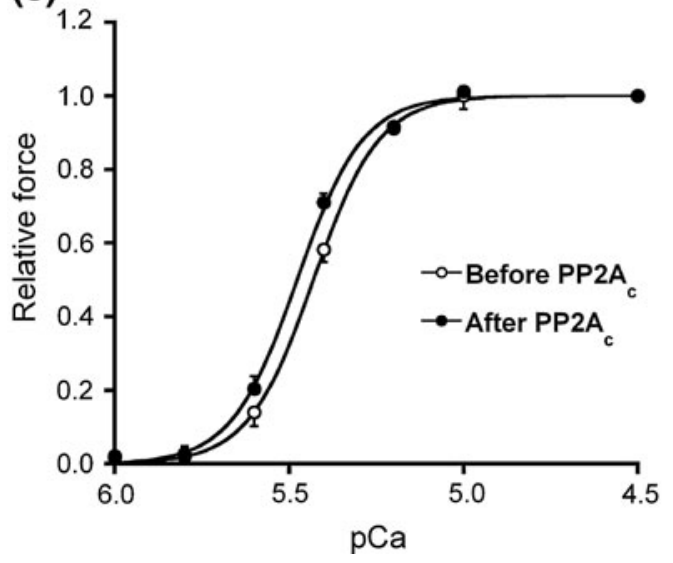


Table 2 Overview of force measurements in NF, ICM and DCM cardiomyocytes before and after PP2A incubation

\begin{tabular}{|c|c|c|c|c|c|}
\hline & $\mathrm{F}_{\max }$ & $\mathrm{F}_{\text {pas }}$ & $\mathrm{pCa}_{50}$ & $\mathrm{nH}$ & $\operatorname{Max} \mathrm{k}_{\mathrm{tr}}$ \\
\hline \multicolumn{6}{|c|}{ Non-Failing (6 hearts, 14 myocytes) } \\
\hline Before PP2A & $19.2 \pm 2.5$ & $1.8 \pm 0.2$ & $5.43 \pm 0.02$ & $5.1 \pm 0.4$ & $0.67 \pm 0.06$ \\
\hline After PP2A & $19.0 \pm 2.5$ & $2.0 \pm 0.2$ & $5.48 \pm 0.01 * *$ & $4.9 \pm 0.2$ & $0.70 \pm 0.03$ \\
\hline \multicolumn{6}{|c|}{ ICM (6 hearts, 14 myocytes) } \\
\hline Before PP2A & $19.3 \pm 3.0$ & $2.1 \pm 0.2$ & $5.53 \pm 0.03^{\#}$ & $4.3 \pm 0.3$ & $0.65 \pm 0.06$ \\
\hline After PP2A & $19.4 \pm 2.6$ & $2.1 \pm 0.1$ & $5.54 \pm 0.03$ & $4.2 \pm 0.3$ & $0.60 \pm 0.03$ \\
\hline \multicolumn{6}{|c|}{ DCM (6 hearts, 13 myocytes) } \\
\hline Before PP2A & $19.6 \pm 2.3$ & $3.2 \pm 0.6$ & $5.50 \pm 0.03$ & $4.4 \pm 0.3$ & $0.60 \pm 0.06$ \\
\hline After PP2A & $19.4 \pm 2.0$ & $3.3 \pm 0.5$ & $5.51 \pm 0.03$ & $4.4 \pm 0.1$ & $0.67 \pm 0.04$ \\
\hline
\end{tabular}

$F_{\max }$ maximal force in $\mathrm{kN} / \mathrm{m}^{2}, F_{\text {pas }}$ passive force in $\mathrm{kN} / \mathrm{m}^{2}, p C a_{50}$ and $n H$ midpoint and steepness of the force-pCa curves, respectively, $M a x k_{t r}$ rate of tension redevelopment $\left(\mathrm{s}^{-1}\right)$ at saturating calcium concentration $(\mathrm{pCa} 4.5)$

** $P<0.01$ before vs. after PP2A treatment (Repeated measures Two-Way ANOVA, $n=6$ )

${ }^{\#} P<0.05$ vs. NF (Two-Way ANOVA (Source of Variation: patient) NS, One-way ANOVA $\left(\mathrm{Ca}^{2+}\right.$ sensitivity NF, ICM, DCM before PP2A) $P=0.06$, Bonferroni's Multiple comparison test NF vs ICM $P<0.05, n=6$ )

Higher basal $\mathrm{Ca}^{2+}$ sensitivity in ischemic heart failure but no effect by PP2A

$\mathrm{Ca}^{2+}$-sensitivity was also determined before (Fig. 2a) and after (Fig. 2b) PP2 $\mathrm{A}_{\mathrm{C}}$ application in failing myocytes by measuring force in activating solutions with submaximal $\left[\mathrm{Ca}^{2+}\right]$ obtained by appropriate mixing of the activating and relaxation solutions. After maximal activation $(\mathrm{pCa}=4.5)$ six measurements were carried out at submaximal $\left[\mathrm{Ca}^{2+}\right]$ followed by a maximal activation. Cells were excluded from the data when the active force dropped more than $20 \%$ between the first and the last measurement at $\mathrm{pCa}=4.5$ before $\mathrm{PP} 2 \mathrm{~A}_{\mathrm{C}}$ treatment of the cells. In ICM myocyte preparations, the basal $\mathrm{Ca}^{2+}$-sensitivity was significantly higher compared to $\mathrm{NF}\left(\Delta \mathrm{pCa}_{50}=0.10 \pm 0.03\right.$ ) (Fig. 2c). However, PP2 $\mathrm{A}_{\mathrm{C}}$ treatment did not further shift force-pCa relationship $\left(\triangle \mathrm{pCa}_{50}=0.01 \pm 0.01\right)$ suggesting maximal dephosphorylation in ICM myocytes. In DCM myocardium, basal $\mathrm{Ca}^{2+}$-sensitivity was also higher compared to $\mathrm{NF}$ $\left(\Delta \mathrm{pCa}_{50}=0.06 \pm 0.04\right)$, however not significantly (Fig. $\left.2 \mathrm{c}\right)$. The application of PP2A 2 did not change the $\mathrm{Ca}^{2+}$-responsiveness of myofilaments compared to untreated DCM myocytes $\left(\Delta \mathrm{pCa}_{50}=0.01 \pm 0.01\right)$.

PP2A does not effect the steepness of the force-pCa curves and rate of tension redevelopment

The steepness of the force-pCa curves $(\mathrm{nH})$ and the maximal rate of tension redevelopment $\left(\max \mathrm{k}_{\mathrm{tr}}\right)$ were also determined before and after $\mathrm{PP} 2 \mathrm{~A}_{\mathrm{C}}$ treatment. Both $\mathrm{nH}$ and $\max k_{\text {tr }}$ were not significantly affected by PP2A in NF, ICM and DCM cardiomyocytes (Table 2).
PP2A dephosphorylates cTnI in donor cardiomyocytes

$\mathrm{NF}$ heart tissue was incubated with $0.5 \mathrm{U}$ or $5 \mathrm{U}$ PP2A to test which myofilament proteins were dephosphorylated by PP2A. Via SYPRO Ruby and ProQ Diamond stainings of gels it was demonstrated that PP2A dephosphorylates cTnI (Fig. 3a). The phosphorylation level of other myofilament proteins (cMyBP-C, troponin $\mathrm{T}$, Desmin and MLC-2) was not affected (data not shown). Western blotting with an antibody raised against bis-phosphorylated cTnI at PKA sites Ser23/24 confirmed that cTnI was dephosphorylated by PP2A at the PKA sites (Fig. 3b).

Reduced PKA-dependent cTnI phosphorylation in human heart failure

To study whether an altered basal phosphorylation level of myofilament proteins is responsible for the higher basal $\mathrm{Ca}^{2+}$-responsiveness in failing hearts, we performed SYPRO Ruby and ProQ Diamond stainings of gels loaded with NF, ICM and DCM LV samples (Fig. 4a). Total phosphorylation of cTnI was lower in failing samples compared to NF hearts (Fig. 4b). No differences were observed in the phosphorylation status of the other myofilament proteins on the gel. The phosphorylation level of cTnI at PKA-sites was studied by Western blotting using a phosphospecific antibody against bis-phosphorylated Ser23/24 of cTnI (Fig. 4c). Here we measured a lower PKA-dependent phosphorylation of cTnI in ICM and DCM hearts compared to NF tissue. 

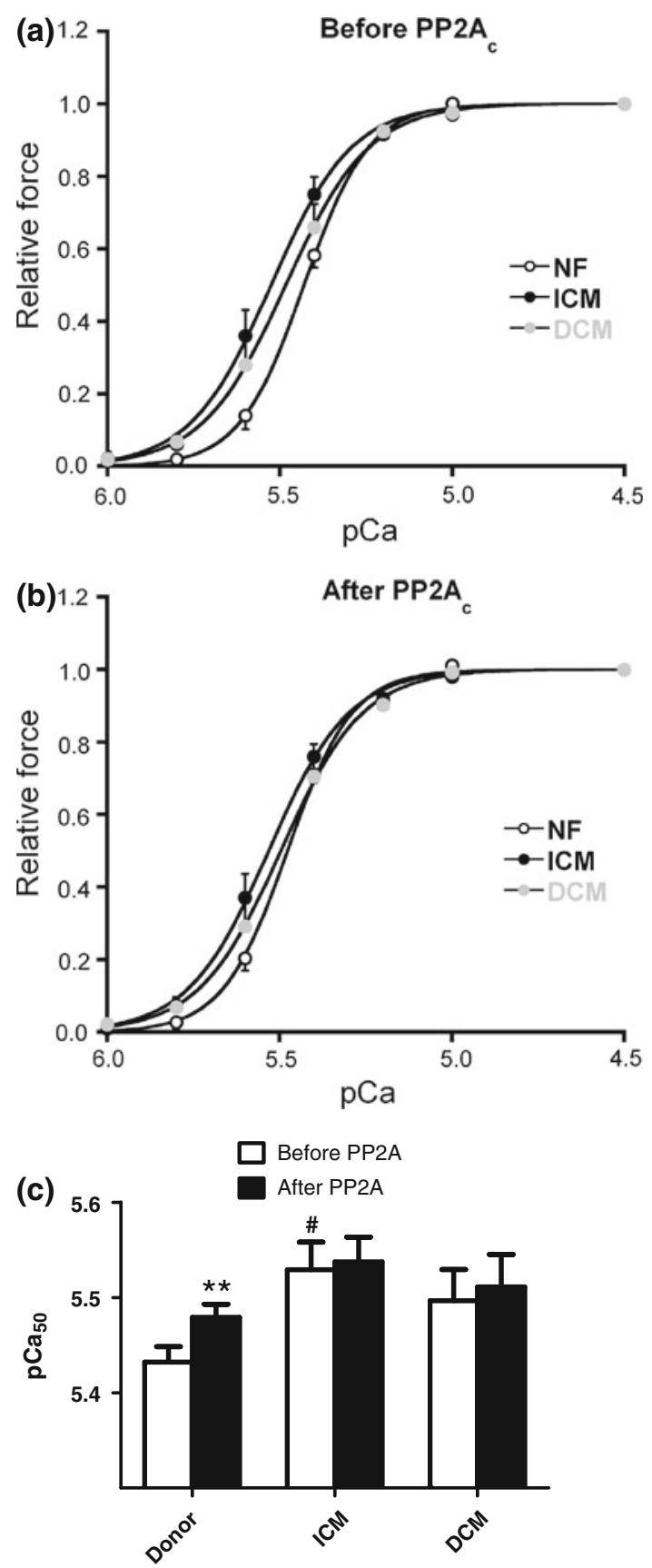

Fig. 2 Isometric force was determined at different $\left[\mathrm{Ca}^{2+}\right]$ before (a) and after (b) treatment with $\mathrm{PP} 2 \mathrm{~A}_{\mathrm{C}}$ in $\mathrm{NF}$ (6 NF, 14 cells) and failing (ICM, 6 patients, 14 cells; DCM, 6 patients, 13 cells) myocytes. Force at submaximal $\left[\mathrm{Ca}^{2+}\right]$ was normalized to the force at saturating $\left[\mathrm{Ca}^{2+}\right] \quad(\mathrm{pCa}=4.5) . \quad \mathrm{PP} 2 \mathrm{~A}_{\mathrm{C}}$ treatment increased $\mathrm{Ca}^{2+}$-sensitivity only in NF cardiomyocytes $(\mathbf{c})$. Basal $\mathrm{Ca}^{2+}$-sensitivity was higher in ICM compared to NF. $* * P<0.01$ before vs. after PP2A treatment (Repeated measures Two-Way ANOVA, $n=6$ ); $\# P<0.05$ vs. NF (Two-Way ANOVA (Source of Variation: patient) NS, One-way ANOVA $\left(\mathrm{Ca}^{2+}\right.$-sensitivity NF, ICM, DCM before PP2A) $P=0.06$, Bonferroni's Multiple comparison test NF vs ICM $P<0.05, n=6)$
Reduced expression of PP2A subunits $\mathrm{C} \alpha / \beta$ and B56 $\alpha$ in failing hearts

To test whether PP2A may be involved in the higher basal myofilament $\mathrm{Ca}^{2+}$-sensitivity of failing human hearts, we determined the expression level of major PP2A subunits in heart samples from patients suffering from ischemic and dilated cardiomyopathy. The catalytic subunit C of PP2A was detected as a $36-\mathrm{kDa}$ protein in cardiac homogenates (Fig. 5a). In RV tissue, PP2 $\mathrm{A}_{\mathrm{C}}$ protein expression was unchanged between all groups investigated, whereas it was reduced by 50 and $56 \%$ in LV of ICM and DCM, respectively, compared to NF hearts. Moreover, we found that the expression of B56 $\alpha$ was decreased in RV tissue by $87 \%$ in DCM but not in ICM hearts compared to NF (Fig. 5b). In contrast, the expression of $\mathrm{B} 56 \alpha$ was reduced in $\mathrm{LV}$ homogenates of both ICM (by 51\%) and DCM (by 62\%) hearts. All samples were also probed with an antibody recognizing the structural subunit of PP2A, A $\alpha$. This subunit runs at $65 \mathrm{kDa}$ on SDS-PAGE (Fig. 5c). Here, we measured a similar protein expression of $\mathrm{A} \alpha$ in ventricles of ICM, DCM, and NF hearts. Linearity of signals detected by immunoblot analysis of heart samples was confirmed (data not shown). Signals were standardized to the expression of calsequestrin, acting as the main $\mathrm{SR} \mathrm{Ca}^{2+}$ storage protein. No difference in the protein expression of calsequestrin was detected between failing and non-failing hearts (data not shown). This is in agreement with data from other heart failure models (Phillips et al. 1998).

Unchanged PP2A but increased PP1 activity in ICM hearts

The measurement of PP activity was used to determine whether the lower PP2 $\mathrm{A}_{\mathrm{C}}$ expression in failing LV myocardium is paralleled by comparable changes of the catalytic activity. Total phosphatase activity was enhanced by $35 \%$ in ICM compared to non-failing homogenates, whereas no difference was observed between DCM and NF (Fig. 6a). To discriminate PP2A activity from PP1 activity, we added $3 \mathrm{nmol} / \mathrm{l}$ okadaic acid (OA) to the reaction mixture, a concentration known to inhibit only PP2A but not PP1 (Cohen 1991). Under our experimental conditions (phosphorylase $a$ as substrate, absence of divalent cations) only PP1 and PP2A is measurable. Therefore, PP2A activity was determined as total activity minus activity in the presence of $3 \mathrm{nmol} / \mathrm{l} \mathrm{OA}$. The contribution of PP2A to the total PP activity was shifted from $52 \%$ in non-failing hearts to $41 \%$ in ICM hearts. However, total PP2A activity was unchanged between ICM and NF preparations (Fig. 6b). The higher total phosphatase activity in ICM reflects an increase in PP1 activity. In DCM hearts, PP2A and PP1 activities were unchanged compared to NF samples (Fig. 6b). 
Fig. 3 NF myocardium $(n=2)$ was treated with $0 \mathrm{U}, 0.5 \mathrm{U}$ or $5 \mathrm{U}$ PP2A for 40 min at RT. Subsequently, proteins were separated by $1 \mathrm{D}$ gel electrophoresis (a). Phosphorylation signals of all proteins on ProQ Diamondstained gels were divided by their SYPRO signals to correct for minor differences in loading. PKA-dependent bisphosphorylation of $\mathrm{cTnI}$ at Ser23/24 was measured by Western blot analysis and normalized to $\alpha$-actinin (b). $c T n T$ troponin T, $M L C-2$ myosin light chain $2, M H C$ myosin heavy chain, $M L C-1$ myosin light chain $1, M W$ molecular weight marker
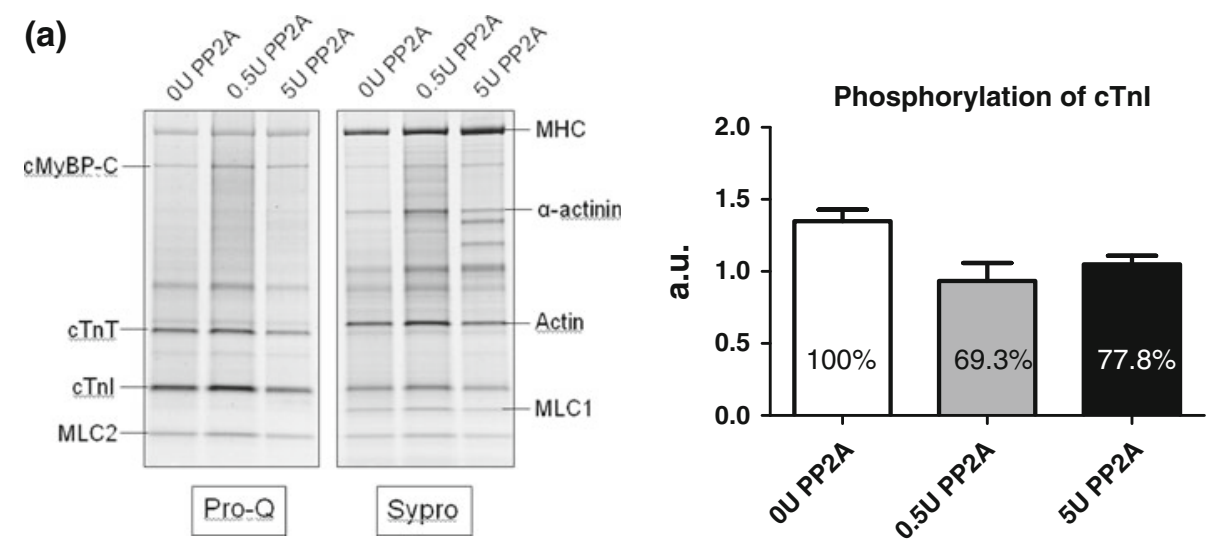

(b)
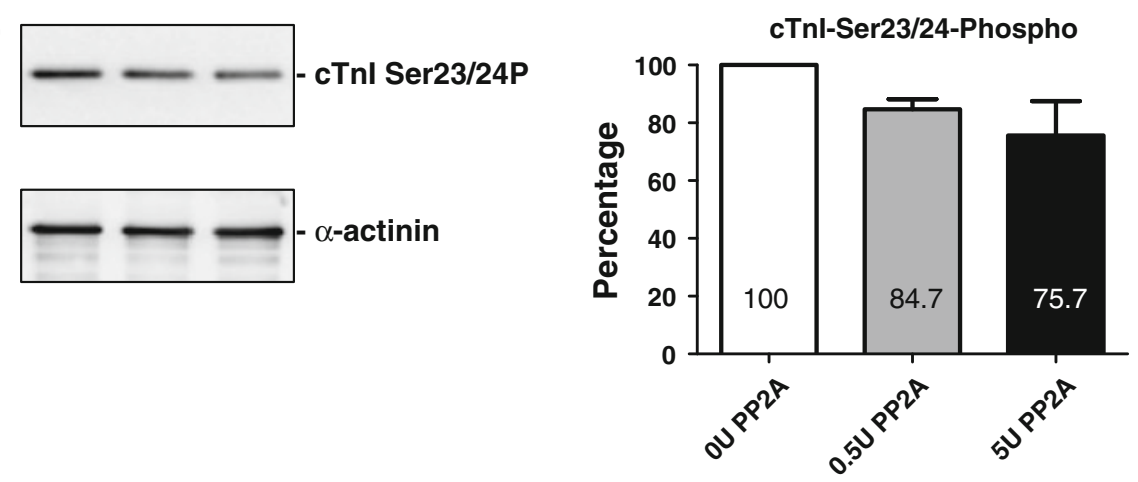

\section{Discussion}

In the present study, we tested whether PP2A is involved in the regulation of myofilament contractility in human Triton-permeabilized cardiomyocytes. The application of PP2A $\mathrm{A}_{\mathrm{C}}$ resulted in a higher $\mathrm{Ca}^{2+}$-sensitivity and dephosphorylation (at PKA sites) of cTnI in non-failing LV myocardium indicating that PP2A may modulate myofilament function by dephosphorylation of cTnI. PP2 $\mathrm{A}_{\mathrm{C}}$ treatment of non-failing myocytes changed the cTnI phosphorylation level as well as the myofilament $\mathrm{Ca}^{2+}$-sensitivity to a level intermediate between the baseline levels observed in non-failing myocytes and failing myocytes. This finding is in line with studies showing cTnI as a main target of PP2A (Deshmukh et al. 2007; Yin et al. 2010). Our data are in contrast to control myocytes of whole rat hearts where the addition of $\mathrm{PP} 2 \mathrm{~A}_{\mathrm{C}}$ had no effect on myofilament $\mathrm{Ca}^{2+}$-sensitivity (Belin et al. 2007). This suggests that PP2A is more effective in human than in rodent myocardium. It is conceivable that differences in the developmental regulation are responsible for the functional differences between both species. For example, mRNA expression, protein levels, and activity of PP2A were lower in adult compared to embryonic rat hearts suggesting a limited role of the enzyme in regulating myofilament contractility in rat heart (Gombosova et al. 1998; Heller et al. 1998).

Next we measured the basal $\mathrm{Ca}^{2+}$-sensitivity of force in failing myocytes. The higher $\mathrm{Ca}^{2+}$-responsiveness in failing compared to NF myocytes is in accordance with previous studies on failing human hearts (van der Velden et al. 2003a; van der Velden et al. 2003b; Wolff et al. 1996). A higher $\mathrm{Ca}^{2+}$-sensitivity in failing hearts has been ascribed to a reduction in the PKA-mediated phosphorylation of cardiac myofilament proteins (Wolff et al. 1996). Indeed, we detected a diminished PKA-dependent cTnI phosphorylation in failing myocardium. This may be caused by a depressed $\beta$-adrenergic signaling characterized by a decreased $\beta$-adrenergic receptor density, a higher $\mathrm{G}_{\mathrm{i}}$ expression, and reduced cAMP levels (Feldman 1993). Consistent with this, the application of PKA abolished the increased $\mathrm{Ca}^{2+}$-sensitivity of force in failing human myocytes leading to values observed in non-failing cells in the absence of the enzyme (van der Velden et al. 2003b). In the latter study a positive correlation between $\mathrm{Ca}^{2+}$-sensitivity and dephosphorylated cTnI was observed. On the other hand, $\mathrm{Ca}^{2+}$-sensitivity is not only dependent on kinase (PKA)-mediated phosphorylation of myofilament proteins but also on the dephosphorylation by PP's. In the present study, we found an unchanged PP2A and a higher PP1 
(a)

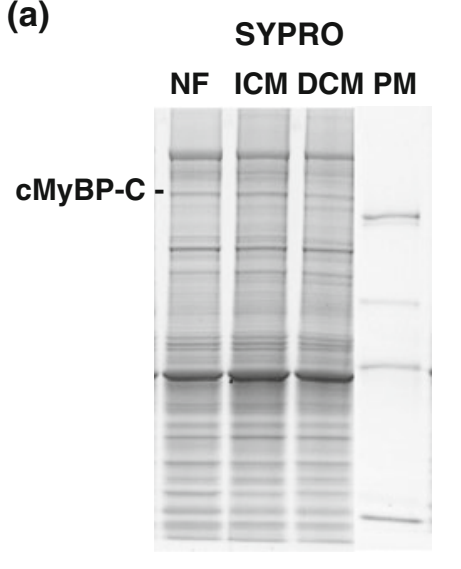

ProQ

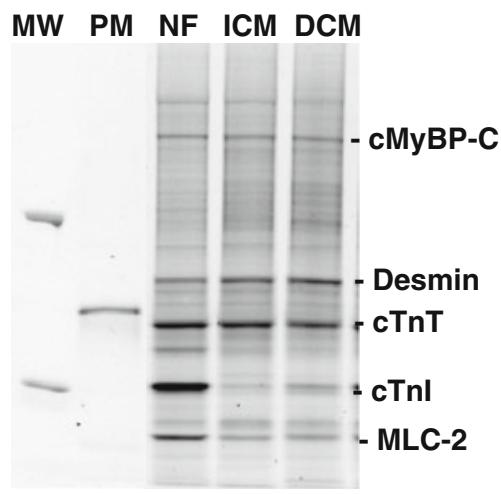

(b)

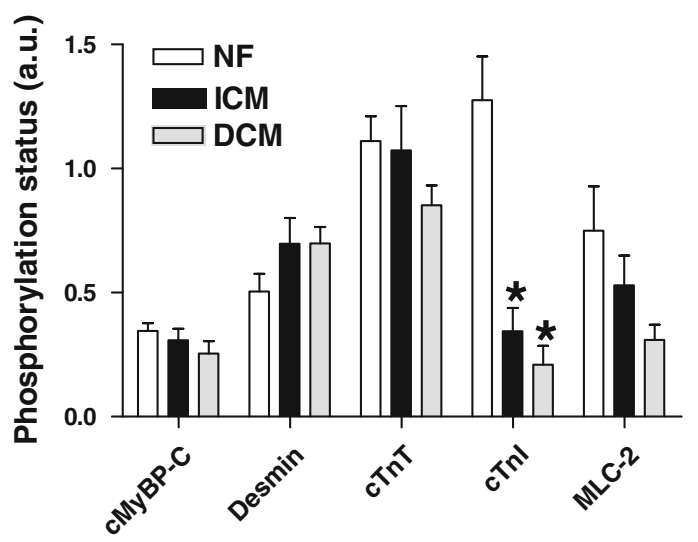

(c)

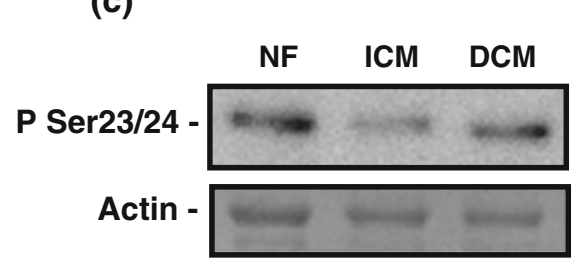

Fig. 4 Myofilament proteins from NF and failing (ICM; DCM) hearts were separated by 1D gel electrophoresis (a). Staining differences between gels were corrected with phosphorylated ovalbumin of the peppermint marker (PM). Phosphorylation signals of all proteins on ProQ Diamond-stained gels were divided by the SYPRO signals of myosin binding protein $\mathrm{C}$ (cMyBP-C) to correct for minor

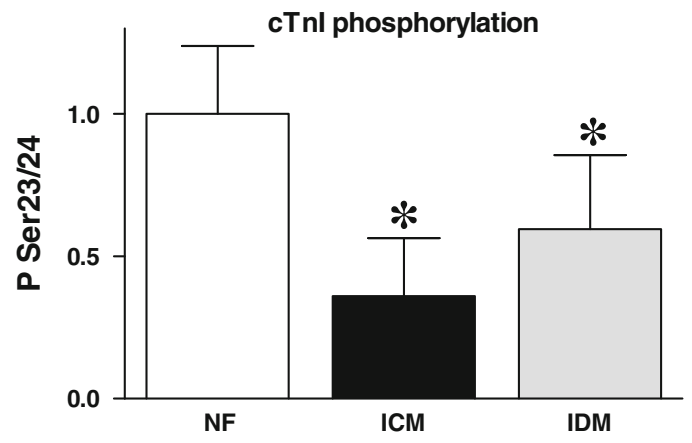

activity in failing hearts. Incubation of non-failing human myocytes with PP1 has been associated with a reduced $\mathrm{Ca}^{2+}$-sensitivity of force and hastened relaxation. These effects were explained by a dephosphorylation of MLC-2 (van der Velden et al. 2003a). It is conceivable that the desensitization by a PP1-dependent MLC-2 dephosphorylation was overcome by the effect of cTnI dephosphorylation resulting in an overall higher basal $\mathrm{Ca}^{2+}$-responsiveness of force in failing samples. In

differences in loading (b). PKA-dependent bis-phosphorylation of cTnI at $\operatorname{Ser}^{23 / 24}$ was measured by Western blot analysis and normalized to actin (c). $c T n T$ troponin $\mathrm{T}, M L C$-2 myosin light chain 2, $M W$ molecular weight marker. ${ }^{*} P<0.05$ vs. NF (post-hoc Bonferroni analysis)

contrast to non-failing myocytes, $\mathrm{PP} 2 \mathrm{~A}_{\mathrm{C}}$ administration had no effect on $\mathrm{Ca}^{2+}$-sensitivity in failing myocytes. In agreement with our data, the addition of purified $\mathrm{PP} 2 \mathrm{~A}_{\mathrm{C}}$ had no effects on $\mathrm{Ca}^{2+}$ sensitivity in a rat model of congestive heart failure (Belin et al. 2007). PP2A-dependent dephosphorylation of native thin filaments isolated from human ICM and DCM ventricles was also associated with an unchanged $\mathrm{Ca}^{2+}$-sensitivity (Noguchi et al. 2004). These data suggest that PP2A does not exert a functional 

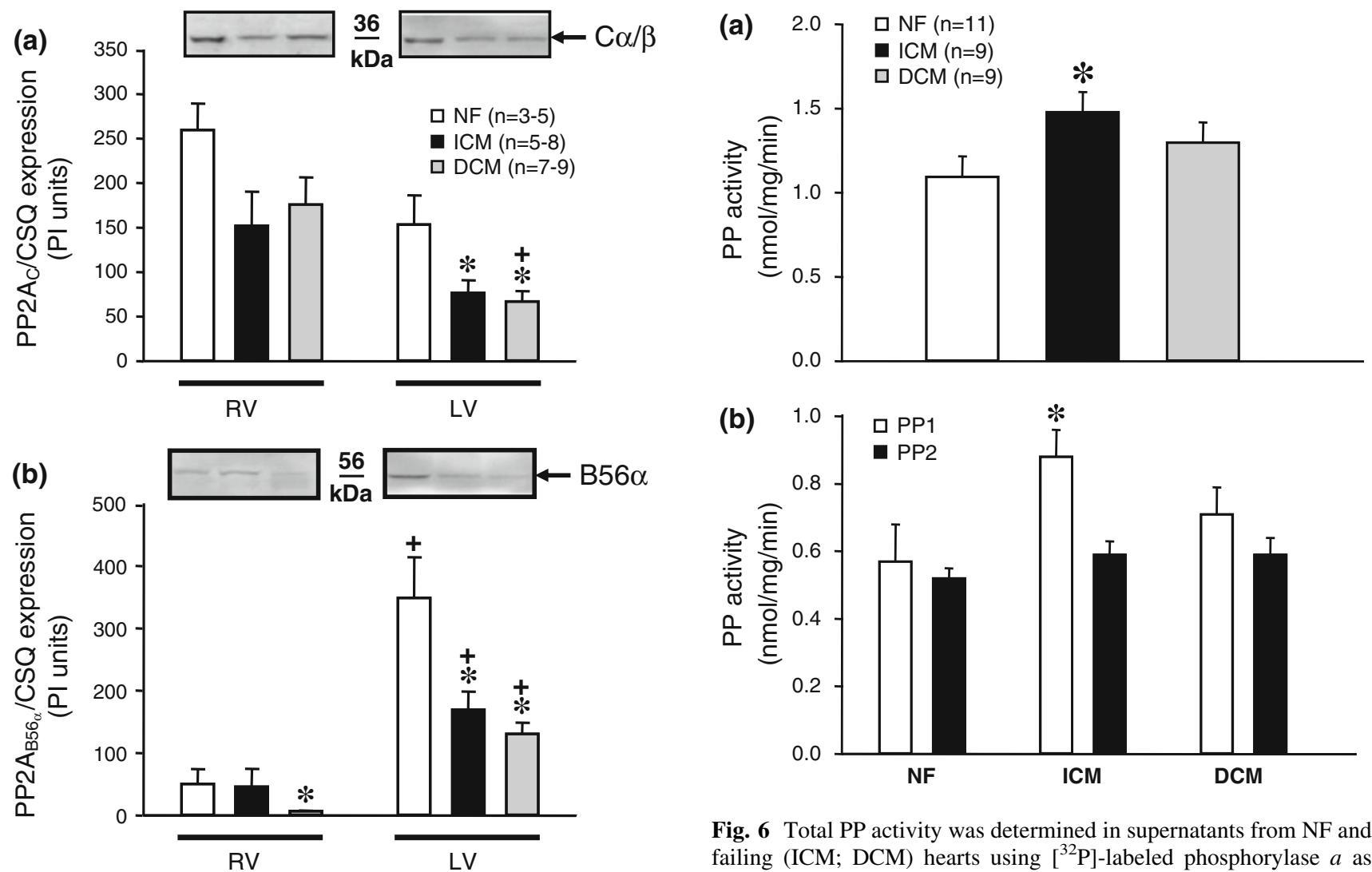

Fig. 6 Total PP activity was determined in supernatants from NF and failing (ICM; DCM) hearts using $\left[{ }^{32} \mathrm{P}\right]$-labeled phosphorylase $a$ as substrate (a). Aliquots of supernatants were also assayed in the presence of $3 \mathrm{nmol} / \mathrm{l}$ okadaic acid, representing the concentration that inhibits only PP2A but not PP1. Therefore, PP2A activity was calculated as the total PP activity minus the activity that was not inhibited by okadaic acid (b). ${ }^{*} P<0.05$ vs. NF

identified as the predominant isoform in human myocardium (Luss et al. 2000). In animal models, an increased PP2A activity was measured in rat hearts after long-term $\beta$-adrenergic stimulation, resulting in a compensated hypertrophy (Boknik et al. 2000). A higher PP2A expression and activity was also detected in hearts of mice with primary pulmonary hypertension (Larsen et al. 2008). In a dog model of acute myocardial infarction, PP2A expression was also enhanced 5 days post occlusion in the border zone (Hund et al. 2009). In contrast, Gupta and co-workers (2003) failed to detect any differences of PP2A activity in microembolized dog hearts, resulting in chronic heart failure. Therefore, it was surprising that the $\mathrm{PP}^{2} \mathrm{~A}_{\mathrm{C}}$ expression was reduced in failing human hearts. It appears that an acute myocardial stress by either mechanical overload (e.g. induced by $\beta$-adrenergic stimulation) or phases of ischemia is associated with an increase of the catalytic subunit, whereas in decompensated heart failure PP2 $\mathrm{A}_{\mathrm{C}}$ expression is decreased. It is also conceivable that the lower $\mathrm{PP} 2 \mathrm{~A}_{\mathrm{C}}$ expression may compensate for the reduced PKA-dependent phosphorylation of $\mathrm{cTnI}$ or the enhanced PP1 activity in ICM heart homogenates. A higher 
PP1 activity was also observed in SR membrane preparations of failing human DCM hearts, whereas no significant difference between PP activities in homogenates was noted (Neumann et al. 1997), as observed in the present study. The detrimental effects of an increased PP1 activity to cardiac contractility were demonstrated in transgenic mice (Carr et al. 2002). Beyond this simplified model of keeping a cellular homeostasis between the main cardiac PP isoforms, the lower expression of PP $2 \mathrm{~A}_{\mathrm{C}}$ in ICM might help to protect the heart tissue against ischemic damages. In this context, fostriecin, an inhibitor of PP2A, limited myocardial infarct size in isolated rabbit hearts when administered after the onset of ischemia (Weinbrenner et al. 1998), whereas transgenic mice with cardiac-specific overexpression of $\mathrm{PP} 2 \mathrm{~A}_{\mathrm{C} \alpha}$ exhibited isles of necrosis, fibrosis, and contractile failure (Gergs et al. 2004).

Interestingly, $\mathrm{PP} 2 \mathrm{~A}_{\mathrm{C}}$ expression was decreased in LV but not in RV chambers of failing hearts. Data on protein expression comparing different chambers of failing hearts are rare. It has been shown that the expression levels of PP2A-associated connexin43 (Ai and Pogwizd 2005; Dupont et al. 2001) and L-type $\mathrm{Ca}^{2+}$ channel (Gruver et al. 1994) are reduced in LV of failing human hearts, indicating a predominant affection of the LV function in heart failure. It remains to be tested whether the lower expression of $\mathrm{PP} 2 \mathrm{~A}_{\mathrm{C}}$ compensates for the reduction of both regulatory proteins in failing LV. Alternatively, the inhibition of PP2A $\mathrm{A}_{C}$ has been shown to minimize the metabolic damage of LV tissue in failing myocardium (Weinbrenner et al. 1998).

In the present study, the lower PP2 $\mathrm{A}_{\mathrm{C}}$ expression was not followed by a corresponding change in activity. This discrepancy may depend on the subcellular distribution of the enzyme which can be modulated by the expression of its regulatory subunits (e.g. B56 $\alpha$ ). In failing human hearts, we have demonstrated a concomitantly reduced expression of $\mathrm{PP} 2 \mathrm{~A}_{\mathrm{B} 56 \alpha}$. As reported above, $\mathrm{B} 56 \alpha$ is thought to be responsible for the subcellular targeting of the PP2A dimeric core enzyme to specific substrates (Depaoliroach et al. 1994). A marked loss in B56 $\alpha$ protein expression was also detected in rat neonatal myocytes after activation of JNK, a stress-related stimulus in the manifestation of cardiac hypertrophy and failure (Glaser et al. 2006). A decrease in PP2 $\mathrm{A}_{\mathrm{B} 56 \alpha}$ expression was also measured in a model of sepsis-associated cardiac dysfunction (Marshall et al. 2009). The down-regulation was associated with a lower expression of PP2A $\mathrm{A}_{\mathrm{C}}$ and increased cTnI phosphorylation levels. This supports the hypothesis that a reduced PP $2 A_{B 56 \alpha}$ expression may impair the targeting of PP $2 A_{C}$ to its subcellular sites. Indeed, decreased levels of RyR-bound PP2 $A_{C}$ were detected in failing human hearts (Marx et al. 2000). This may contribute to a hyperphosphorylation of the channel, resulting in a defective regulation of excitation-contraction coupling. Here, we detected higher expression levels of $\mathrm{PP} 2 \mathrm{~A}_{\mathrm{B} 56 \alpha}$ in $\mathrm{LV}$ compared to $\mathrm{RV}$ of non-failing and failing hearts. These differences may point to localized responses to cardiac overload. For instance, $\beta$ MHC transcript levels were lower in LV suggesting that there is more need for an increase in contractility in LV compared to RV (Sharma et al. 2003). Consistently, LV exhibits a higher RyR expression (Munch et al. 2000) which enables a stronger SR $\mathrm{Ca}^{2+}$ release and high contractile velocity of myofibrils. We suggest that a higher $\mathrm{PP}_{2} \mathrm{~A}_{\mathrm{B} 56 \alpha}$ expression in LV may help to target the catalytic subunit to the more abundant RyR.

Our data indicate that PP2A may be involved in the regulation of the myofilament $\mathrm{Ca}^{2+}$-sensitivity in nonfailing human hearts. In contrast, PP2A had no effect on the enhanced basal $\mathrm{Ca}^{2+}$-sensitivity in failing myocytes which might result from the depressed PKA-dependent basal phosphorylation of $\mathrm{cTnI}$ in failing hearts. The lower expression of the catalytic subunit and B56 $\alpha$ in ICM might be compensatory mechanisms in order to normalize the higher basal $\mathrm{Ca}^{2+}$-sensitivity.

Acknowledgments The study was supported by the IMF Münster (to U.K.) and the Deutsche Forschungsgemeinschaft (BO1263/9-1 and NE393/32-1).

Disclosures No conflicts of interest are declared by the authors.

Open Access This article is distributed under the terms of the Creative Commons Attribution Noncommercial License which permits any noncommercial use, distribution, and reproduction in any medium, provided the original author(s) and source are credited.

\section{References}

Ai X, Pogwizd SM (2005) Connexin 43 downregulation and dephosphorylation in nonischemic heart failure is associated with enhanced colocalized protein phosphatase type $2 \mathrm{~A}$. Circ Res 96:54-63

Belin RJ, Sumandea MP, Allen EJ, Schoenfelt K, Wang H, Solaro RJ, de Tombe PP (2007) Augmented protein kinase C-alpha-induced myofilament protein phosphorylation contributes to myofilament dysfunction in experimental congestive heart failure. Circ Res 101:195-204

Boknik P, Fockenbrock M, Herzig S, Knapp J, Linck B, Luss H, Muller FU, Muller T, Schmitz W, Schroder F, Neumann J (2000) Protein phosphatase activity is increased in a rat model of longterm beta-adrenergic stimulation. Naunyn Schmiedebergs Arch Pharmacol 362:222-231

Boknik P, Khorchidi S, Bodor GS, Huke S, Knapp J, Linck B, Luss H, Muller FU, Schmitz W, Neumann J (2001) Role of protein phosphatases in regulation of cardiac inotropy and relaxation. Am J Physiol Heart Circ Physiol 280:H786-H794

Brewis N, Ohst K, Fields K, Rapacciuolo A, Chou D, Bloor C, Dillmann W, Rockman H, Walter G (2000) Dilated cardiomyopathy in transgenic mice expressing a mutant A subunit of protein phosphatase 2A. Am J Physiol Heart Circ Physiol 279:H1307-H1318 
Carr AN, Schmidt AG, Suzuki Y, del Monte F, Sato Y, Lanner C, Breeden K, Jing SL, Allen PB, Greengard P, Yatani A, Hoit BD, Grupp IL, Hajjar RJ, Depaoli-Roach AA, Kranias EG (2002) Type 1 phosphatase, a negative regulator of cardiac function. Mol Cell Biol 22:4124-4135

Chen Y, Rajashree R, Liu QH, Hofmann P (2003) Acute p38 MAPK activation decreases force development in ventricular myocytes. Am J Physiol Heart Circ Physiol 285:H2578-H2586

Cohen P (1991) Classification of protein-serine threonine phosphatases - identification and quantitation in cell extracts. Methods Enzymol 201:389-398

Depaoliroach AA, Park IK, Cerovsky V, Csortos C, Durbin SD, Kuntz MJ, Sitikov A, Tang PM, Verin A, Zolnierowicz S (1994) Serine/threonine protein phosphatases in the control of cell function. Adv Enzyme Regul 34:199-224

Deshmukh PA, Blunt BC, Hofmann PA (2007) Acute modulation of PP2a and troponin I phosphorylation in ventricular myocytes: studies with a novel PP2a peptide inhibitor. Am J Physiol Heart Circ Physiol 292:H792-H799

DuBell WH, Lederer WJ, Rogers TB (1996) Dynamic modulation of excitation-contraction coupling by protein phosphatases in rat ventricular myocytes. J Physiol 493:793-800

DuBell WH, Gigena MS, Guatimosim S, Long XL, Lederer WJ, Rogers TB (2002) Effects of PP1/PP2A inhibitor calyculin A on the E-C coupling cascade in murine ventricular myocytes. Am J Physiol Heart Circ Physiol 282:H38-H48

Duncker DJ, Boontje NM, Merkus D, Versteilen A, Krysiak J, Mearini G, El-Armouche A, de Beer VJ, Lamers JMJ, Carrier L, Walker LA, Linke WA, Stienen GJM, van der Velden J (2009) Prevention of myofilament dysfunction by beta-blocker therapy in post-infarct remodeling. Circ Heart Failure 2:233-242

Dupont E, Matsushita T, Kaba RA, Vozzi C, Coppen SR, Khan N, Kaprielian R, Yacoub MH, Severs NJ (2001) Altered connexin expression in human congestive heart failure. J Mol Cell Cardiol 33:359-371

Fabiato A (1981) Myoplasmic free calcium-concentration reached during the twitch of an intact isolated cardiac cell and during calcium-induced release of calcium from the sarcoplasmic reticulum of a skinned cardiac cell from the adult rat or rabbit ventricle. J Gen Physiol 78:457-497

Feldman AM (1993) Modulation of adrenergic receptors and G-transduction proteins in failing human ventricular myocardium. Circulation 87:27-34

Gergs U, Boknik P, Buchwalow I, Fabritz L, Matus M, Justus I, Hanske G, Schmitz W, Neumann J (2004) Overexpression of the catalytic subunit of protein phosphatase $2 \mathrm{~A}$ impairs cardiac function. J Biol Chem 279:40827-40834

Glaser ND, Lukyanenko YO, Wang YB, Wilson GM, Rogers TB (2006) JNK activation decreases PP2A regulatory subunit B56 alpha expression and mRNA stability and increases AUF1 expression in cardiomyocytes. Am J Physiol Heart Circ Physiol 291:H1183-H1192

Gombosova I, Boknik P, Kirchhefer U, Knapp J, Luss H, Muller FU, Muller T, Vahlensieck U, Schmitz W, Bodor GS, Neumann J (1998) Postnatal changes in contractile time parameters, calcium regulatory proteins, and phosphatases. Am J Physiol Heart Circ Physiol 274:H2123-H2132

Gruver EJ, Morgan JP, Stambler BS, Gwathmey JK (1994) Uniformity of calcium channel number and isometric contraction in human right and left ventricular myocardium. Basic Res Cardiol 89:139-148

Gupta RC, Mishra S, Rastogi S, Imai M, Habib O, Sabbah HN (2003) Cardiac SR-coupled PP1 activity and expression are increased and inhibitor 1 protein expression is decreased in failing hearts. Am J Physiol Heart Circ Physiol 285:H2373-H2381
Hall DD, Feekes JA, Don ASA, Shi M, Hamid J, Chen L, Strack S, Zamponi GW, Horne MC, Hell JW (2006) Binding of protein phosphatase $2 \mathrm{~A}$ to the L-type calcium channel $\mathrm{Ca}(\mathrm{v}) 1.2$ next to Ser1928, its main PKA site, is critical for Ser1928 dephosphorylation. Biochemistry 45:3448-3459

Hamdani N, Borbely A, Veenstra SPGR, Zaremba R, dos Remedios C, Niessen HWM, Paulus WJ, Stienen GJM, van der Velden J (2010) Diverse alterations in sarcomeric protein composition and function in ischemic and idiopathic dilated cardiomyopathy. J Muscle Res Cell Motil 31:289-301

Heller FA, Xue C, Fisher A, Everett AD (1998) Expression and mapping of protein phosphatase $2 \mathrm{~A}$ (alpha) in the developing rat heart. Pediatr Res 43:68-76

Herzig S, Neumann J (2000) Effects of serine/threonine protein phosphatases on ion channels in excitable membranes. Physiol Rev 80:173-210

Hund TJ, Wright PJ, Dun W, Snyder JS, Boyden PA, Mohler PJ (2009) Regulation of the ankyrin-B-based targeting pathway following myocardial infarction. Cardiovasc Res 81:742-749

Ito A, Koma YI, Sohda M, Watabe K, Nagano T, Misumi Y, Nojima H, Kitamura Y (2003) Localization of the PP2A B56 gamma regulatory subunit at the Golgi complex-possible role in vesicle transport and migration. Am J Pathol 162:479-489

Janssens V, Goris J (2001) Protein phosphatase 2A: a highly regulated family of serine/threonine phosphatases implicated in cell growth and signalling. Biochem J 353:417-439

Kirchhefer U, Neumann J, Baba HA, Begrow F, Kobayashi YM, Reinke U, Schmitz W, Jones LR (2001) Cardiac hypertrophy and impaired relaxation in transgenic mice overexpressing triadin 1. J Biol Chem 276:4142-4149

Kooij V, Boontje NM, Zaremba R, Jaquet K, dos Remedios C, Stienen GJM, van der Velden J (2010a) Protein kinase C $\alpha$ and $\varepsilon$ phosphorylation of troponin and myosin binding protein $\mathrm{C}$ reduce $\mathrm{Ca}^{2+}$-sensitivity in human myocardium. Basic Res Cardiol 105:289-300

Kooij V, Saes M, Jaquet K, Zaremba R, Foster DB, Murphy AM, dos Remedios C, van der Velden J, Stienen GJM (2010b) Effect of troponin I Ser23/24 phosphorylation on $\mathrm{Ca}^{2+}$-sensitivity in human myocardium depends on the phosphorylation background. J Mol Cell Cardiol 48:954-963

Larsen KO, Lygren B, Sjaastad I, Krobert KA, Arnkvaern K, Florholmen G, Larsen AKR, Levy FO, Tasken K, Skjonsberg $\mathrm{OH}$, Christensen G (2008) Diastolic dysfunction in alveolar hypoxia: a role for interleukin-18-mediated increase in protein phosphatase 2A. Cardiovasc Res 80:47-54

Luss H, Klein-Wiele O, Boknik P, Herzig S, Knapp J, Linck B, Muller FU, Scheld HH, Schmid C, Schmitz W, Neumann J (2000) Regional expression of protein phosphatase type 1 and $2 \mathrm{~A}$ catalytic subunit isoforms in the human heart. $\mathrm{J}$ Mol Cell Cardiol 32:2349-2359

Macdougall LK, Jones LR, Cohen P (1991) (Identification of the major protein phosphatases in mammalian cardiac muscle which dephosphorylate phospholamban. Eur J Biochem 196:725-734

Marshall M, Anilkumar N, Layland J, Walker SJ, Kentish JC, Shah AM, Cave AC (2009) Protein phosphatase 2A contributes to the cardiac dysfunction induced by endotoxemia. Cardiovasc Res 82:67-76

Marx SO, Reiken S, Hisamatsu Y, Jayaraman T, Burkhoff D, Rosemblit N, Marks AR (2000) PKA phosphorylation dissociates FKBP12.6 from the calcium release channel (ryanodine receptor): defective regulation in failing hearts. Cell 101: 365-376

McCright B, Rivers AM, Audlin S, Virshup DM (1996) The B56 family of protein phosphatase $2 \mathrm{~A}$ (PP2A) regulatory subunits encodes differentiation-induced phosphoproteins that target 
PP2A to both nucleus and cytoplasm. J Biol Chem 271:2208122089

Munch G, Bolck B, Sugaru A, Schwinger RHG (2000) Isoform expression of the sarcoplasmic reticulum $\mathrm{Ca}^{2+}$ release channel (ryanodine channel) in human myocardium. J Mol Med 78: $352-360$

Neumann J, Boknik P, Herzig S, Schmitz W, Scholz H, Wiechen K, Zimmermann N (1994) Biochemical and electrophysiological mechanisms of the positive inotropic effect of calyculin-A, a protein phosphatase inhibitor. J Pharmacol Exp Ther 271:535-541

Neumann J, Herzig S, Boknik P, Apel M, Kaspareit G, Schmitz W, Scholz H, Tepel M, Zimmermann N (1995) On the cardiac contractile, biochemical and electrophysiological effects of cantharidin, a phosphatase inhibitor. J Pharmacol Exp Ther 274:530-539

Neumann J, Eschenhagen T, Jones LR, Linck B, Schmitz W, Scholz H, Zimmermann N (1997) Increased expression of cardiac phosphatases in patients with end-stage heart failure. J Mol Cell Cardiol 29:265-272

Noguchi T, Hunlich M, Camp PC, Begin KJ, El Zaru M, Patten R, Leavitt BJ, Ittleman FP, Alpert NR, LeWinter MM, VanBuren P (2004) Thin filament-based modulation of contractile performance in human heart failure. Circulation 110:982-987

Phillips RM, Narayan P, Gomez AM, Dilly K, Jones LR, Lederer WJ, Altschuld RA (1998) Sarcoplasmic reticulum in heart failure: central player or bystander? Cardiovasc Res 37:346-351

Price NE, Mumby MC (2000) Effects of regulatory subunits on the kinetics of protein phosphatase 2A. Biochemistry 39:1131211318

Schulze DH, Muqhal M, Lederer WJ, Ruknudin AM (2003) Sodium/ calcium exchanger (NCX1) macromolecular complex. J Biol Chem 278:28849-28855

Sharma S, Razeghi P, Shakir A, Keneson BJ, Clubbb F, Taegtmeyer $\mathrm{H}$ (2003) Regional heterogeneity in gene expression profiles: a transcript analysis in human and rat heart. Cardiology 100:73-79

Shi YG (2009) Serine/threonine phosphatases: mechanism through structure. Cell 139:468-484 van der Velden J, Klein LJ, van der Bijl M, Huybregts MAJM, Stooker W, Witkop J, Eijsman L, Visser CA, Visser FC, Stienen GJM (1998) Force production in mechanically isolated cardiac myocytes from human ventricular muscle tissue. Cardiovasc Res $38: 414-423$

van der Velden J, Papp Z, Boontje NM, Zaremba R, de Jong JW, Janssen PML, Hasenfuss G, Stienen GJM (2003a) The effect of myosin light chain 2 dephosphorylation on $\mathrm{Ca}^{2+}$-sensitivity of force is enhanced in failing human hearts. Cardiovasc Res 57:505-514

van der Velden J, Papp Z, Zaremba R, Boontje NM, de Jong JW, Owen VJ, Burton PBJ, Goldmann P, Jaquet K, Stienen GJM (2003b) Increased $\mathrm{Ca}^{2+}$-sensitivity of the contractile apparatus in end-stage human heart failure results from altered phosphorylation of contractile proteins. Cardiovasc Res 57:37-47

Weinbrenner C, Baines CP, Liu GS, Armstrong SC, Ganote CE, Walsh AH, Honkanen RE, Cohen MV, Downey JM (1998) Fostriecin, an inhibitor of protein phosphatase 2A, limits myocardial infarct size even when administered after onset of ischemia. Circulation 98:899-905

Wolff MR, Buck SH, Stoker SW, Greaser ML, Mentzer RM (1996) Myofibrillar calcium sensitivity of isometric tension is increased in human dilated cardiomyopathies-role of altered beta-adrenergically mediated protein phosphorylation. J Clin Invest 98:167-176

Yin X, Cuello F, Mayr U, Hao Z, Hornshaw M, Ehler E, Avkiran M, Mayr M (2010) Proteomics analysis of the cardiac myofilament subproteome reveals dynamic alterations in phosphatase subunit distribution. Mol Cell Proteomics 9:497-509

Zaremba R, Merkus D, Hamdani N, Lamers JMJ, Paulus WJ, dos Remedios C, Duncker DJ, Stienen GJM, van der Velden J (2007) Quantitative analysis of myofilament protein phosphorylation in small cardiac biopsies. Proteomics Clin Appl 1:1285-1290

Zhou XW, Mudannayake M, Green M, Gigena MS, Wang GH, Shen RF, Rogers TB (2007) Proteomic studies of PP2A-B56 gamma 1 phosphatase complexes reveal phosphorylation-regulated partners in cardiac local signaling. J Proteome Res 6:3433-3442 